\title{
PENGARUH KEPEMIMPINAN DAN PENGEMBANGAN SUMBER DAYA MANUSIA TERHADAP KEPUASAN KERJA, MOTIVASI KERJA, DAN KINERJA KARYAWAN BANK SULSELBAR
}

\author{
Agung Widhi Kurniawan \\ agung234wk@yahoo.com \\ Universitas Negeri Makassar
}

\begin{abstract}
This study aims to explain the effect of leadership and human resource development on job satisfaction, job motivation and employees performance. Analysis by using Structural Equation Modeling (SEM) with alpha 5\% to test the significance of research variable. The data were taken from all Bank Sulselbar employees using cluster random sampling technique. The total respondents were 184 respondents. Questionnaire (main instrument), interview, observation, and documentary were used in collecting the data. Results of analysis (at significance level of 5\%) showed that: 1) leadership has a significant effect on job satisfaction, 2) human resource development has a significant effect on job satisfaction, 3) leadership has a significant effect on job motivation, 4) human resource development has a significant effect on job motivation, 5) leadership has a significant effect on employee performance, 6) human resource development has a significant influence employee performance, 7) job satisfaction has a significant effect on job motivation, 8) job satisfaction has a significant effect on employee performance, and 9) job motivation does not significantly affect on employee performance.
\end{abstract}

Key words: leadership, human resources development, job satisfaction, job motivation, employees performance.

\begin{abstract}
ABSTRAK
Studi ini bertujuan untuk menjelaskan pengaruh kepemimpinan dan pengembangan sumber daya manusia terhadap kepuasan kerja, motivasi kerja serta kinerja karyawan. Analisis dilakukan menggunakan Structural Equation Modeling (SEM) dengan alpha 5\% untuk menguji signifikansi variabel peneletian. Data diperoleh dari karyawan tetap Bank Sulselbar yang ditetapkan sebagai sampel berdasarkan teknik cluster random sampling. Total responden adalah 184 karyawan. Pengumpu lan data menggunakan kuesioner (sebagai instrumen utama), wawancara, pengamatan, dan dokumen tasi. Hasil analisis (pada tingkat signifikansi 5\%) menunjukkan bahwa: 1) kepemimpinan berpengaruh signifikan terhadap kepuasan kerja, 2) pengembangan sumber daya manusia berpengaruh signifikan terhadap kepuasan kerja, 3) kepemimpinan berpengaruh signifikan terhadap motivasi kerja, 4) pengembangan sumber daya manusia berpengaruh signifikan terhadap motivasi kerja, 5) kepemimpinan berpengaruh signifikan terhadap kinerja karyawan, 6) pengembangan sumber daya manusia berpengaruh signifikan terhadap kinerja karyawan, 7) kepuasan kerja berpengaruh signifikan terhadap motivasi kerja, 8) kepuasan kerja berpengaruh signifikan terhadap kinerja karyawan, dan 9) motivasi kerja berpengaruh tidak signifikan terhadap kinerja karyawan.
\end{abstract}

Kata kunci : kepemimpinan, pengembangan sumber daya manusia, kepuasan kerja, motivasi kerja, kinerja karyawan.

\section{PENDAHULUAN}

Persaingan bisnis di sektor perbankan semakin tajam. Manajemen bank harus proaktif dan dapat memberi jasa yang memuaskan kepada nasabahnya agar dapat bertahan dan berkembang, caranya adalah memahami persepsi nasabah mengenai jasa bank serta menerapkannya sesuai dengan apa yang diinginkan nasabah. 
Para karyawan dituntut untuk dapat melaksanakan tugas yang dibebankan kepadanya secara profesional, bekerja keras, disiplin, jujur, loyalitas tinggi, dan penuh dedikasi untuk keberhasilan pekerjaannya (Hamid dan Rowi, 2003:40).

PT. Bank Pembangunan Daerah Sulawesi Selatan, selanjutnya dalam penelitian ini disebut sebagai Bank Sulselbar, merupakan perusahaan yang bergerak di sektor perbankan. Bank Sulselbar dalam upaya pembentukan keunggulan kompetitif dituntut untuk mampu melakukan perbaikan terus-menerus (continuous improvement). Bank Sulselbar harus dinamis dan senantiasa memberi pelayanan yang terbaik terhadap pelanggannya. Apabila Bank Sulselbar tidak dikelola secara profesional, maka dapat dipastikan akan menimbulkan ketidakmampuan untuk bersaing, sehingga Bank Sulselbar akan mengalami kerugian atau kemunduran.

Kinerja Bank Sulselbar secara finansial mengalami peningkatan dari tahun ke tahun. Namun demikian, peningkatan kinerja finansial tidak secara langsung me nunjukkan peningkatan kinerja karyawan. Masalah kinerja karyawan yang dihadapi Bank Sulselbar selama ini, antara lain: penyelesaian tugas oleh karyawan secara berkualitas tidak sesuai dengan yang diharapkan perusahaan, timbulnya ketidakpuasan (kurang puas) sebagian nasabah oleh sistem pelayanan Bank Sulselbar, karyawan tidak disiplin baik berdasarkan aspek kehadiran kerja maupun kepatuhan terhadap peraturan jam kerja sehingga berakibat pada penyelesaian pekerjaan tidak tepat waktu dan efisiensi waktu terabaikan, pemahaman karyawan atas job description masih bervariasi sehingga penyelesaian tugas belum mencapai hasil yang optimal, terdapat ketidaksesuaian antara hasil evaluasi kinerja individual dan hasil evaluasi kinerja unit/perusahaan sehingga timbul rasa ketidakadilan bagi sebagian karyawan atas evaluasi kinerja oleh manajemen, sistem kerja yang cenderung bersifat rutinitas menyebabkan rendahnya kreativitas- inovatif karyawan, dan penerapan sistem manajemen kinerja tidak secara langsung meningkatkan kinerja karyawan.

Bank Sulselbar, sebagai pengelola dana pemerintah daerah Provinsi dan Pemerintah Kabupaten/Kota, dapat menjalankan kegiatan operasionalnya dengan kondisi perekonomian di Sulawesi Selatan yang relatif baik. Kondisi ini membuat karyawan merasa berada dalam "comfort zone" yang menyebabkan tidak ada motivasi bekerja lebih giat, selain itu juga didukung dengan tanpa adanya penetapan sasaran kinerja. Oleh karenanya, tahun 2012 direncanakan akan diterapkan manajemen kinerja secara bertahap agar kinerja Bank Sulselbar dapat ditingkatkan melalui peningkatan kinerja karyawan, antara lain melalui peningkatan kedisiplinan dan target penyelesaian tugas sehingga jabatan dapat lebih dipertanggungjawabkan, serta perilaku karyawan diarahkan sesuai dengan nilai-nilai budaya perusahaan.

Dalam upaya peningkatan kinerja karyawan yang diharapkan maka dipandang perlu melakukan penelitian yang menguji dan menganalisis faktor-faktor yang mempengaruhi kinerja karyawan. Kajian tentang sumber daya manusia dan keorganisasian yang menyoroti faktor-faktor yang mempengaruhi kinerja telah banyak dilakukan. Faktor yang sangat umum dan hampir selalu dikaji dalam penilaian kinerja ini adalah faktor peran kepemimpinan dan pengembangan sumber daya manusia. Kepemimpinan dan pengembangan sumber daya manusia diharapkan mampu mencipta kan kepuasan kerja karyawan. Kepuasan kerja yang dirasakan akan menimbulkan motivasi untuk menghasilkan kinerja karyawan yang diharapkan.

Penelitian ini menguji dan menganalisis pengaruh kepemimpinan dan pengembangan sumber daya manusia terhadap kepuasaan kerja dan motivasi kerja serta kinerja karyawan Bank Sulselbar yang secara teknis ditunjukkan melalui analisis model persamaan struktural atau structural equation modeling (SEM) yang berbasis teori 
dan konsep, dari paket program analysis of moment structure (AMOS). Adanya variabel kepuasan kerja dan motivasi kerja dijadikan variabel intervening dalam penelitian ini karena diharapkan akan mempengaruhi secara tidak langsung faktor kepemimpinan dan pengembangan sumber daya manusia yang merupakan variabel eksogen terhadap variabel kinerja karyawan yang merupakan variabel endogen. Populasi dalam penelitian ini adalah seluruh karyawan tetap Bank Sulselbar yang ada di kantor pusat maupun di kantor cabang sebanyak 917 orang. Dari sejumlah populasi tersebut, sebagian populasi akan dijadikan sampel dengan mengacu pada kriteria teknik sampling.

Fokus penelitian ini akan menguji beberapa faktor independen yang mempengaruhi kinerja karyawan Bank Sulselbar, yaitu: kepemimpinan dan pengembangan sumber daya manusia. Diduga beberapa faktor independen tersebut berpengaruh positif terhadap kinerja karyawan, dalam arti semakin baik kepemimpinan yang terjadi di Bank Sulselbar dan semakin baik penerapan program pengembangan sumber daya manusia yang diterapkan di Bank Sulselbar maka akan semakin baik pula tingkat kepuasan kerja, motivasi kerja, dan kinerja karyawannya. Fokus penelitian ini adalah ingin menguji pengaruh faktor mana yang paling berpengaruh terhadap kinerja karyawan.

Perbedaan penelitian ini dengan penelitian-penelitian sebelumnya adalah bahwa penelitian ini menggunakan faktor kepemimpinan dan pengembangan sumber daya manusia sebagai variabel independen, kepuasan kerja dan motivasi kerja sebagai variabel intervening, serta kinerja karyawan sebagai variabel dependen. Diduga faktor kepemimpinan dan pengembangan sumber daya manusia dalam sebuah organisasi akan menimbulkan rasa puas pada diri karyawan sehingga dapat mempengaruhi sikap dan perilaku karyawan untuk selalu termotivasi, bersemangat, optimis, dan per- caya diri yang pada akhirnya mampu membawa karyawan mencapai kinerja yang optimal.

Rumusan masalah dalam penelitian ini adalah:

1. Apakah kepemimpinan berpengaruh terhadap kepuasan kerja?

2. Apakah pengembangan sumber daya manusia berpengaruh terhadap kepuasan kerja?

3. Apakah kepemimpinan berpengaruh terhadap motivasi kerja?

4. Apakah pengembangan sumber daya manusia berpengaruh signifikan terhadap motivasi kerja?

5. Apakah kepemimpinan berpengaruh terhadap kinerja karyawan?

6. Apakah pengembangan sumber daya manusia berpengaruh terhadap kinerja karyawan?

7. Apakah kepuasan kerja berpengaruh terhadap motivasi kerja?

8. Apakah kepuasan kerja berpengaruh terhadap kinerja karyawan?

9. Apakah motivasi kerja berpengaruh terhadap kinerja karyawan?

Tujuan penelitian ini adalah menguji dan menganalisis pengaruh variabel kepemimpinan dan pengembangan sumber daya manusia terhadap kepuasan kerja, motivasi kerja, dan kinerja karyawan. Hasil penelitian ini diharap dapat memberi bahan pertimbangan bagi manajemen Bank Sulselbar dalam pengambilan kebijakan, keputusan, dan program pengembangan bisnisnya.

\section{TINJAUAN TEORETIS Kepemimpinan}

Kepemimpinan adalah suatu proses mempengaruhi orang lain guna mencapai tujuan tertentu (Winandi, 2002:47; Hughes et al., 2002; Robbins, 2002:163; Yukl, 2005:8). Dalam kerangka bisnis seorang manajer adalah seorang pemimpin manakala ia mampu mempengaruhi bawahan, rekan kerja atau bahkan atasan mereka untuk 
mengarahkan usaha-usaha mereka guna pencapaian tujuan organisasi.

Hampir sebagian besar pendefinisian kepemimpinan memiliki titik kesamaan kata kunci yakni "suatu proses mempengaruhi". Akan tetapi ditemukan konseptualisasi kepemimpinan dalam banyak hal berbeda. Perbedaan dalam hal "siapa yang menggunakan pengaruh, tujuan dari upaya mempengaruhi, cara-cara menggunakan pengaruh tersebut". Perbedaan tersebut dapat diukur dari kualitas pribadi, tindakan administrasi, hubungan kerja, pemberian penghargaan, dan pemecahan masalah sebagai indikator dari kepemimpinan.

\section{Pengembangan Sumber Daya Manusia}

Pengembangan sumber daya manusia merupakan upaya yang mengindikasi adanya pergerakan menuju situasi yang lebih baik atau meningkat bagi seorang individu dalam organisasi (Mahmudah, 2007; Price, 2003:558; Ayuningtias, 2007:10). Pengembangan sumber daya manusia memiliki peran yang vital dalam upaya mengarahkan, men dorong, memotivasi peningkatan/pengembangan kemampuan dan keterampilan para karyawan yang diimplementasikan pada pekerjaannya untuk mencapai keefektifan sumber daya manusia dalam organisasi (Lee and Bruvold, 2003). Pengembangan sumber daya manusia mempunyai konsep untuk pengembangan diri, program pelatihan serta kemajuan karir untuk memenuhi kebutuhan organisasi akan keahlian di masa yang akan datang.

\section{Kepuasan Kerja}

Kepuasan kerja merupakan orientasi individu yang berpengaruh terhadap peran dalam bekerja. Kepuasan kerja merupakan penilaian, perasaan atau sikap seseorang atau karyawan terhadap pekerjaannya dan hubungan dengan lingkungan kerja, jenis pekerjaan, kompensasi, hubungan sosial di tempat kerja, dan lain-lain. Kepuasan kerja adalah dipenuhinya beberapa keinginan dan kebutuhan melalui kegiatan kerja atau bekerja.
Para ahli memberi definisi atau konsep mengenai kepuasan kerja dengan ungkapan bahasa dan tinjauan dari sudut pandang yang berbeda-beda namun makna yang terkandung dari definisi yang mereka ungkapkan pada umumnya sama, yaitu bahwa kepuasan kerja adalah sikap dan perasaan umum dari seorang pekerja terhadap pekerjaannya (Davis and Newstroom, 2001: 103; Robbins, 2002:184).

\section{Motivasi Kerja}

Motivasi kerja merupakan motivasi individual yang menggerakkan diri karyawan yang terarah atau tertuju untuk mencapai tujuan organisasi perusahaan (Winandi, 2002:1; Robbins, 2002:198). Motivasi kerja menjadi salah satu determinan penting bagi pencapaian prestasi individu di suatu organisasi. Dampak dari motivasi kerja adalah terciptanya gairah kerja karyawan sehingga produktivitas kerja karyawan akan meningkat.

Motivasi merupakan pendorong yang ada dalam diri individu yang memberi daya penggerak untuk melakukan sesuatu sebaik mungkin. Apabila individu tersebut mempunyai motivasi yang tinggi maka dia akan berkinerja tinggi sehingga tujuan yang akan dicapai dan yang diinginkan perusahaan dapat terwujud. Dengan demikian titik tolak motivasi adalah individu karena motivasi berada pada setiap individu. Keanekaragaman motivasi akan menciptakan keanekaragaman pola perilaku karyawan di suatu perusahaan.

\section{Kinerja Karyawan}

Kinerja karyawan dapat diartikan sebagai prestasi kerja, yakni hasil kerja secara kualitas dan kuantitas yang dicapai oleh seorang tenaga kerja dalam melaksanakan tugasnya sesuai dengan tanggung jawab yang diberikan kepadanya (Gibson et al.,1997; Mahmudah, 2007). Secara teoretis, faktor yang mempengaruhi pencapaian kinerja adalah faktor kemampuan (ability) dan faktor motivasi (motivation). Kemampuan merupakan determinasi dari pengetahuan 
(knowledge) dan keterampilan (skill), sedangkan, motivasi terbentuk dari sikap (attitude) dalam menghadapi situasi (situation) kerja (Mangkunegara, 2004:79).

\section{Penelitian Sebelumnya dan Pengembang- an Hipotesis \\ Pengaruh Kepemimpinan Terhadap Kepua san Kerja}

Kepemimpinan merupakan salah satu faktor penting yang dapat mempengaruhi kepuasan kerja. Perilaku dari seorang pemimpin dapat mempengaruhi kepuasan dan kinerja dari bawahan (Yukl, 2005:7; Pierce and Newstrom, 2006). Penelitian dilakukan oleh Challagalla and Shervani (2006) menemukan bahwa kepemimpinan berpengaruh signifikan terhadap kepuasan kerja karyawan.

$\mathrm{H}_{1}$ : Kepemimpinan berpengaruh signi fikan terhadap Kepuasan Kerja.

\section{Pengaruh Pengembangan Sumber Daya Manusia dan Kepuasan Kerja}

Pengembangan sumber daya manusia merupakan suatu proses mengembangkan keahlian karyawan untuk dapat bekerja secara profesional. Ketika karyawan dapat bekerja secara profesional, maka kepuasan kerja dapat dicapai (Hassan et al., 2006). Pengembangan sumber daya manusia juga berarti memberikan kewenangan pada karyawan (empowerment), memberi kesempatan pada individu untuk mengontrol karir mereka serta untuk mengembangkan pola kehidupannya, sehingga dapat meningkatkan kepuasan kerja (Price, 2003:559).

$\mathrm{H}_{2}$ : Pengembangan Sumber Daya Manusia berpengaruh signifikan terhadap Kepuasan Kerja Karyawan.

\section{Pengaruh Kepemimpinan dan Motivasi Kerja}

Kepemimpinan dalam suatu organisasi sangat penting peranannya dalam rangka memimpin aktivitas-aktivitas dengan upaya penggunaan pengaruh yang bukan pemaksaan dalam memotivasi karyawan untuk mencapai tujuan tertentu melalui proses komunikasi (Ruvendi, 2005; Mahmudah, 2007). Motivasi kerja merupakan kondisi atau energi yang menggerakkan diri karyawan yang terarah atau tertuju untuk mencapai tujuan organisasi perusahaan (Mangkunegara, 2004:61). Penelitian dilakukan oleh Webb (2007) menemukan bahwa kepemimpinan memiliki peranan besar dan berpengaruh signifikan terhadap motivasi kerja.

$\mathrm{H}_{3}$ : Kepemimpinan berpengaruh signifikan terhadap Motivasi Kerja.

\section{Pengaruh Pengembangan Sumber Daya Manusia dan Motivasi Kerja}

Pengembangan sumber daya manusia akan berpengaruh terhadap motivasi kerja apabila pengembangan sumber daya manusia dilaksanakan secara sistematis, artinya adanya upaya untuk memaksimalkan potensi karyawan di dalam organisasi, mencurahkan waktu, biaya, dan pemikiran untuk meningkatkan kompetensi penting yang dimiliki oleh para karyawan. Hal tersebut dapat memotivasi karyawan, meningkatkan keahliannya serta memperlihatkan bahwa karyawan tersebut berharga bagi organisasi (Robbins, 2002; Price, 2003). Youndt et al. (1996) menunjukkan bahwa investasi dalam pengembangan sumber daya manusia merepresentasi suatu strategi komitmen tinggi yang mempengaruhi motivasi kerja karyawan.

$\mathrm{H}_{4}$ : Pengembangan Sumber Daya Manusia berpengaruh signifikan terhadap Motivasi Kerja.

\section{Pengaruh Kepemimpinan dan Kinerja Karyawan}

Kepemimpinan dapat mempengaruhi kinerja karyawan. Keberhasilan atau efektivitas kepemimpinan seseorang tidak saja diukur bagaimana memberdayakan bawahannya, akan tetapi juga kemampuannya menjalankan kebijakan perusahaan melalui cara atau gaya kepemimpinannya sehingga dapat meningkatkan kinerja karyawan. 
Kinerja karyawan merupakan perwujudan kerja yang dilakukan oleh karyawan yang biasanya dipakai sebagai dasar penilaian terhadap karyawan atau organisasi. Kinerja yang baik merupakan suatu langkah menuju tercapainya tujuan organisasi (Hughes et al., 2002; Yukl, 2005:7). Prananta (2008) memberi bukti empiris bahwa kepemimpinan berpengaruh signifikan terhadap kinerja karyawan.

$\mathrm{H}_{5}$ : Kepemimpinan berpengaruh signifikan terhadap Kinerja Karyawan.

\section{Pengaruh Pengembangan Sumber Daya Manusia dan Kinerja Karyawan}

Investasi dalam pengembangan sumberdaya manusia (seperti: pembelajaran, pelatihan dan pengembangan sistem, pemberian imbalan dan pengakuan, serta penyediaan sistem informasi iklim pengembangan sumber daya manusia) akan mendorong peningkatan kinerja secara individual maupun organisasi (Hassan et al., 2006). Hasil penelitian Siregar (2009) menunjukkan bahwa terdapat pengaruh pengembangan sumber daya manusia terhadap kinerja pegawai kantor dinas Perhubungan Kota Medan.

$\mathrm{H}_{6}$ : Pengembangan Sumber Daya Manusia berpengaruh signifikan terhadap Kinerja Karyawan.

\section{Pengaruh Kepuasan Kerja dan Motivasi Kerja}

Karyawan akan termotivasi dalam bekerja apabila ada kaitan langsung antara tujuan dari pekerjaan (task goal) yang akan dicapai dengan sistem imbalan material dan non material (reward), yang akan mendorong perilaku bekerja karyawan (work behavior) untuk berprestasi tinggi karena kebutuhan dan harapan karyawan dapat terpuaskan (Herbert dalam Mahmudah, 2007; Laily, 2008).

Hasil penelitian Laily (2008) menemukan bahwa kepuasan kerja secara langsung berpengaruh signifikan terhadap kinerja karyawan tingkat manajerial. Kepuasan kerja karyawan merupakan salah satu aspek penting yang harus diperhatikan dalam usaha meningkatkan kemampuan sumber daya manusia suatu organisasi. Apabila kepuasan kerja para karyawan tingkat manajerial sudah terpenuhi, mereka akan cenderung memiliki motivasi yang tinggi dalam bekerja yang akan meningkatkan produktivitasnya.

$\mathrm{H}_{7}$ : Kepuasan Kerja berpengaruh signifikan terhadap Motivasi Kerja.

\section{Pengaruh Kepuasan Kerja dan Kinerja Karyawan}

Kepuasan akan berpengaruh terhadap kinerja karyawan apabila kepuasan yang diperoleh karyawan dari pekerjaanya karena terdapat kesesuaian antara apa yang diharapkan dan apa yang diterimanya mampu mendorong karyawan mencapai kinerja yang optimal. Kondisi kepuasan atau ketidakpuasan kerja tersebut menjadi umpan balik yang akan mempengaruhi kinerja karyawan (Handoko, 1996:196).

Penelitian dilakukan oleh Laily (2008) menemukan bahwa kepuasan kerja secara langsung berpengaruh signifikan terhadap kinerja karyawan tingkat manajerial. Penelitian yang dilakukan oleh Ostroff (1992) menemukan bahwa ada hubungan yang positif antara kepuasan kerja dan kinerja karyawan. Penelitian yang dilakukan oleh Laschinger et al. (2001) juga menemukan bahwa kepuasan kerja mempunyai hubungan yang positif terhadap kinerja karyawan.

$\mathrm{H}_{8}$ : Kepuasan Kerja berpengaruh signifikan terhadap Motivasi Kerja.

\section{Pengaruh Motivasi Kerja dan Kinerja Karyawan}

Motivasi kerja adalah faktor yang sangat penting dalam peningkatan kinerja karyawan. Kinerja karyawan merupakan hasil perkalian atau fungsi dari motivasi kerja. Karyawan yang termotivasi dalam bekerja akan mampu mencapai kinerja yang optimal. Kinerja yang baik merupakan suatu langkah untuk tercapainya tujuan 
organisasi (Mangkunegara, 2004:61; Mahmudah, 2007; Laily, 2008).

Hasil penelitian Sutadji (2008) yang membuktikan bahwa motivasi kerja berpengaruh signifikan terhadap kinerja karyawan.

Setiap karyawan mempunyai kebutuhan bersifat material dan non material yang selalu meningkatkan intensitasnya dan mendorong/mengarahkan kinerja. Motivasi merupakan predisposisi psikis bagi perilaku, yakni manusia berperilaku adalah tergantung pada motivasinya.

Namun hasil penelitian yang dilakukan Prananta (2008) membuktikan bahwa motivasi berpengaruh tidak signifikan terhadap kinerja karyawan. Secara tidak langsung melalui variabel perilaku kerja, motivasi berpengaruh positif dan signifikan terhadap kinerja karyawan.

$\mathrm{H}_{9}$ : Motivasi Kerja berpengaruh signifikan terhadap Kinerja Karyawan.

\section{Model Penelitian}

Model Penelitian ditunjukkan pada Gambar 1.

\section{METODE PENELITIAN Populasi dan Sampel}

Populasi dalam penelitian ini adalah karyawan Bank Sulselbar, tidak termasuk direksi dan pimpinan divisi, sebanyak 917 orang. Pengambilan sampel menggunakan teknik cluster proportional random sampling atau pengambilan sampel secara acak berdasarkan cluster dan setiap cluster persentasenya adalah sama. Cluster berdasarkan kantor Bank Sulselbar yang terdiri dari 31 kantor di Sulawesi Selatan, 2 kantor cabang di Sulawesi Barat, dan 1 kantor cabang di Jakarta. Ukuran sampel: $n=8 x$ jumlah indikator. Penelitian ini menggunakan 23 indikator, maka $\mathrm{n}=8 \times 23$, sehingga diperoleh jumlah sampel sebanyak 184 responden.

Persentase jumlah responden yang dibutuhkan dari populasi adalah (184/917) $x 100 \%=20 \%$.

Pengambilan sampel pada masingmasing unit kerja (grup dan seksi) di setiap kantor Bank Sulselbar juga dilakukan secara proporsional sesuai jumlah karyawan pada unit kerja tersebut dengan menggunakan teknik pengundian.

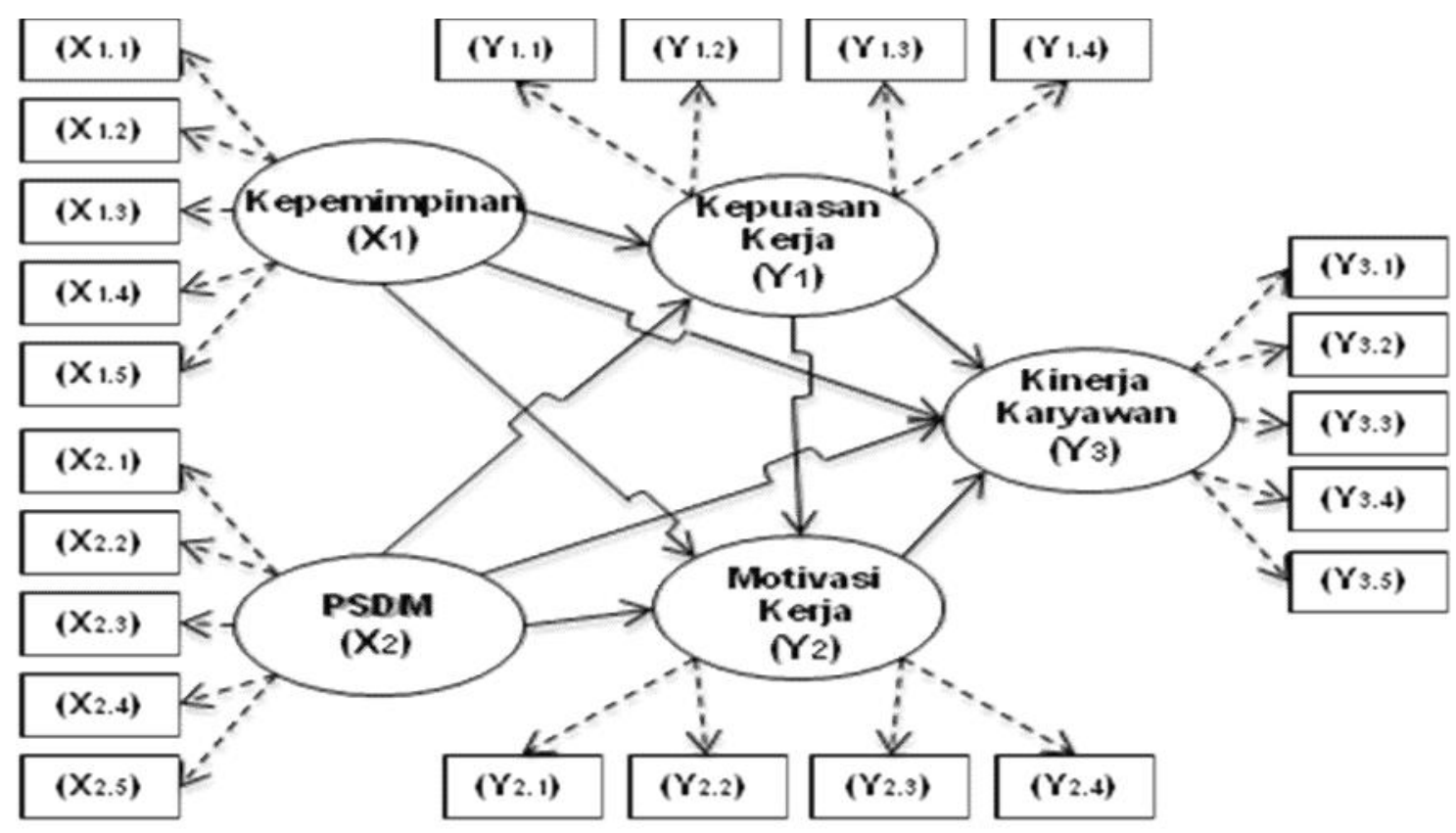

Gambar 1 Model Penelitian 


\section{Variabel Penelitian}

Penelitian ini menggunakan 5 (lima) variabel, yaitu: kepemimpinan $\left(X_{1}\right)$ dan pengembangan sumber daya manusia $\left(X_{2}\right)$, berfungsi sebagai variabel independen atau variabel eksogen; kepuasan kerja $\left(Y_{1}\right)$ dan motivasi kerja $\left(\mathrm{Y}_{2}\right)$, berfungsi sebagai variabel antara atau variabel intervening, dan berfungsi juga sebagai variabel endogen; serta kinerja karyawan $\left(\mathrm{Y}_{3}\right)$, berfungsi sebagai variabel dependen atau variabel endogen.

\section{Kepemimpinan $\left(X_{1}\right)$}

Kepemimpinan adalah suatu proses mempengaruhi orang lain guna mencapai tujuan tertentu (Winandi, 2002:47; Hughes et al., 2002; Robbins, 2002:163; Yukl, 2005:8). Variabel kepemimpinan menggunakan indikator: kualitas pribadi, tindakan administratif, hubungan kerja, pemberian penghargaan, dan pemecahan masalah.

\section{Pengembangan Sumber Daya Manusia $\left(X_{2}\right)$}

Pengembangan sumber daya manusia merupakan upaya yang mengindikasi adanya pergerakan menuju situasi yang lebih baik atau meningkat bagi seorang individu dalam organisasi (Mahmudah, 2007; Price, 2003:558; Ayuningtias, 2007:10). Variabel pengembangan sumber daya manusia meng gunakan indikator: praktik seleksi, program pelatihan dan pengembangan, pengembangan karir, sistem evaluasi kinerja, dan jaminan kerja.

\section{Kepuasan Kerja ( $\left.\mathrm{Y}_{1}\right)$}

Kepuasan kerja adalah sikap dan perasaan umum seorang karyawan terhadap pekerjaannya (Davis and Newstroom, 2001:63; Kreitner and Kinicki, 2004:271; Robbins, 2002:184). Variabel kepuasan kerja menggunakan indikator: supervisi, operating procedures, kesempatan promosi, dan rekan kerja.

\section{Motivasi Kerja $\left(\mathrm{Y}_{2}\right)$}

Motivasi kerja merupakan motivasi individual yang menggerakkan diri kar- yawan yang terarah atau tertuju untuk mencapai tujuan organisasi perusahaan (Winandi, 2002:1; Robbins, 2002:198). Variabel motivasi kerja menggunakan indikator: orientasi tugas, pemanfataan waktu, kepercayaan pemimpin, dan penghargaan.

\section{Kinerja Karyawan $\left(\mathrm{Y}_{3}\right)$}

Kinerja karyawan dapat diartikan sebagai prestasi kerja, yakni hasil kerja secara kualitas dan kuantitas yang dicapai oleh seorang tenaga kerja dalam melaksanakan tugasnya sesuai dengan tanggung jawab yang diberikan kepadanya (Bernardin and Russel, 1993:379; Gibson et al.,1997; Mahmudah, 2007). Variabel kinerja karyawan menggunakan indikator: kualitas, kuantitas, ketepatan waktu, kebutuhan akan pengawasan, dan dampak interpersonal.

\section{ANALISIS DAN PEMBAHASAN}

Setelah dilakukan uji validitas dan reliabilitas pada semua variabel laten dengan hasil variabel yang valid dan reliabel, data berdistribusi normal multivariat, tidak terdapat masalah singularitas pada data yang dianalisis, tidak terjadi multikolinearitas dan tidak ada outlier, maka tahap selanjutnya adalah pengujian kesesuaian model yang hasilnya disajikan pada Gambar 2.

Hasil pengujian model lengkap di atas dengan program AMOS secara lengkap dapat dilihat pada Tabel 1.

Tabel 1 menunjukkan bahwa dari 8 (delapan) kriteria yang digunakan untuk menilai layak/tidaknya suatu model ternyata 6 kriteria menyatakan baik. Hal ini dapat dikatakan bahwa model dapat diterima, yang berarti ada kesesuaian antara model dengan data.

Pengujian hipotesis dilakukan dengan uji $\mathrm{t}$ ( $t$ test) pada masing-masing jalur pengaruh langsung secara parsial, dan secara ringkas disajikan pada Tabel 2.

Interpretasi masing-masing koefisien jalur dan hasil pengujian hipotesis adalah sebagai berikut: 


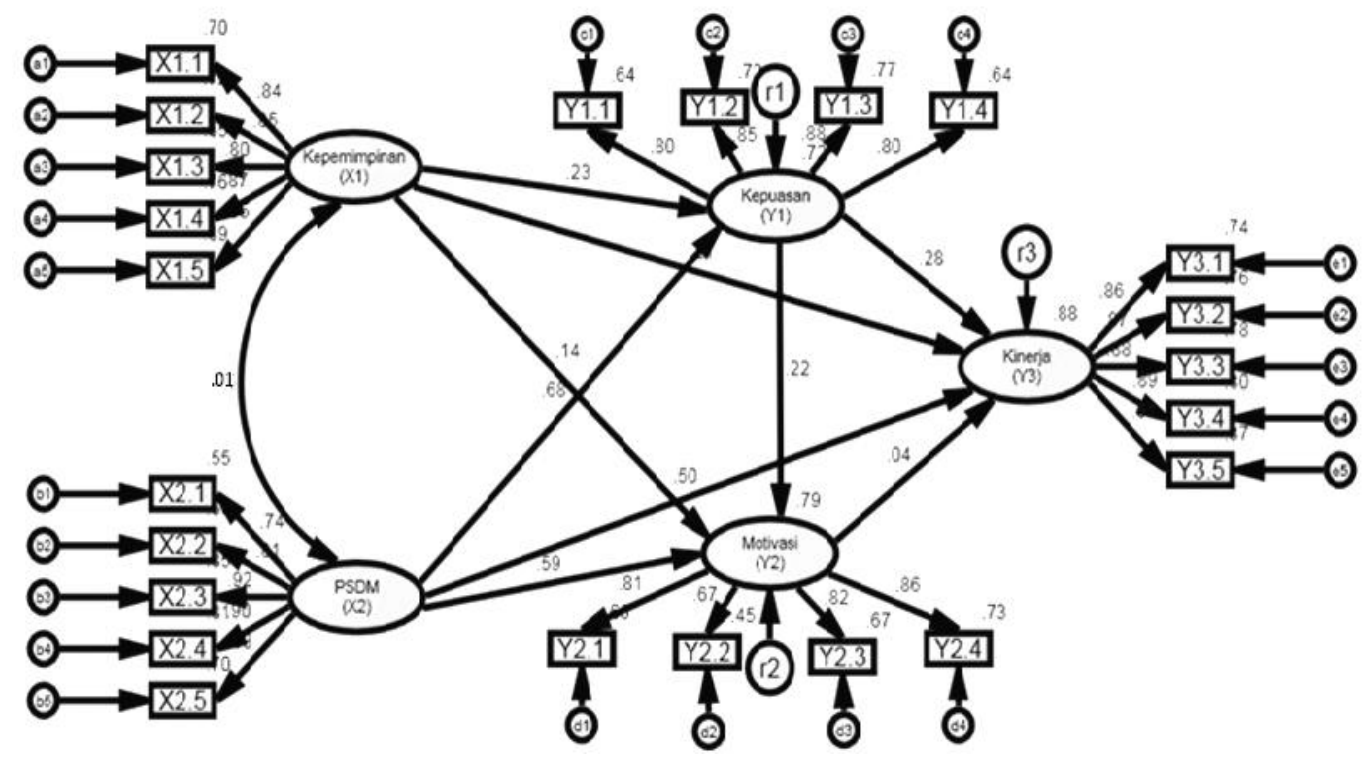

Gambar 2

Hasil Analisis Jalur

Tabel 1

Hasil Pengujian Kesesuaian Model

\begin{tabular}{lccc}
\hline \hline \multicolumn{1}{c}{ Kriteria } & Cut-off Value & Hasil Analisis & Evaluasi Model \\
\hline Chi - Square & Diharapkan kecil & 327.580 & \multicolumn{2}{c}{$\chi^{2}$ dengan $\mathrm{df}=220$ adalah } \\
Significance Probability & $\geq 0,05$ & 0,008 & Tidak Baik \\
RMSEA & $\leq 0,08$ & 0,071 & Baik \\
GFI & $\geq 0,90$ & 0,936 & Baik \\
AGFI & $\geq 0,90$ & 0,914 & Baik \\
CMIN/DF & $\leq 2,00$ & 1,489 & Baik \\
TLI & $\geq 0,90$ & 0,951 & Baik \\
CFI & $\geq 0,90$ & 0,967 & Baik \\
\hline
\end{tabular}

Sumber: Hasil analisis, diolah

Tabel 2

Hasil Pengujian Hipotesis

\begin{tabular}{lcccl}
\hline \hline \multicolumn{1}{c}{ Variabel } & Koef. & C.R. & Prob. & Keterangan \\
\hline Kepemimpinan $\left(\mathrm{X}_{1}\right) \rightarrow$ Kepuasan Kerja $\left(\mathrm{Y}_{1}\right)$ & 0,230 & 3,328 & 0,000 & Signifikan \\
PSDM $\left(\mathrm{X}_{2}\right) \rightarrow$ Kepuasan Kerja $\left(\mathrm{Y}_{1}\right)$ & 0,679 & 8,138 & 0,000 & Signifikan \\
Kepemimpinan $\left(\mathrm{X}_{1}\right) \rightarrow$ Motivasi Kerja $\left(\mathrm{Y}_{2}\right)$ & 0,144 & 2,117 & 0,034 & Signifikan \\
PSDM $\left(\mathrm{X}_{2}\right) \rightarrow$ Motivasi Kerja $\left(\mathrm{Y}_{2}\right)$ & 0,586 & 5,571 & 0,000 & Signifikan \\
Kepemimpinan $\left(\mathrm{X}_{1}\right) \rightarrow$ Kinerja Karyawan $\left(\mathrm{Y}_{3}\right)$ & 0,215 & 3,952 & 0,000 & Signifikan \\
PSDM $\left(\mathrm{X}_{2}\right) \rightarrow$ Kinerja Karyawan $\left(\mathrm{Y}_{3}\right)$ & 0,497 & 4,823 & 0,000 & Signifikan \\
Kepuasan Kerja $\left(\mathrm{Y}_{1}\right) \rightarrow$ Motivasi Kerja $\left(\mathrm{Y}_{2}\right)$ & 0,225 & 2,132 & 0,033 & Signifikan \\
Kepuasan Kerja $\left(\mathrm{Y}_{1}\right) \rightarrow$ Kinerja Karyawan $\left(\mathrm{Y}_{3}\right)$ & 0,277 & 3,251 & 0,001 & Signifikan \\
Motivasi Kerja $\left(\mathrm{Y}_{2}\right) \rightarrow$ Kinerja Karyawan $\left(\mathrm{Y}_{3}\right)$ & 0,037 & 0,368 & 0,713 & Tidak Signifikan \\
\hline
\end{tabular}

Sumber: Hasil analisis, diolah 
1. Kepemimpinan $\left(X_{1}\right)$ berpengaruh secara langsung, positif, dan signifikan terhadap Kepuasan Kerja $\left(\mathrm{Y}_{1}\right)$. Hal ini terlihat dari koefisien jalur yang bertanda positif sebesar 0,230 dengan nilai C.R. sebesar 3,328 dan diperoleh probabilitas signifikansi $(\mathrm{p})$ sebesar 0,000 yang lebih kecil dari taraf signifikansi $(\alpha)$ yang ditentukan sebesar 0,05. Koefisien jalur sebesar 0,230, berarti setiap ada kenaikan Kepemimpinan $\left(X_{1}\right)$ maka akan menaikkan Kepuasan Kerja $\left(\mathrm{Y}_{1}\right)$ sebesar 0,230. Dengan demikian hipotesis 1 terbukti dan diterima.

2. Pengembangan Sumber Daya Manusia $\left(\mathrm{X}_{2}\right)$ berpengaruh secara langsung, positif, dan signifikan terhadap Kepuasan Kerja $\left(\mathrm{Y}_{1}\right)$. Hal ini terlihat dari koefisien jalur yang bertanda positif sebesar 0,679 dengan nilai C.R. sebesar 8,138 dan diperoleh probabilitas signifikansi (p) sebesar 0,000 yang lebih kecil dari taraf signifikansi $(\alpha)$ yang ditentukan sebesar 0,05. Koefisien jalur sebesar 0,679, berarti setiap ada kenaikan Pengembangan Sumber Daya Manusia $\left(X_{2}\right)$ maka akan menaikkan Kepuasan Kerja $\left(\mathrm{Y}_{1}\right)$ sebesar 0,679. Dengan demikian hipotesis 2 terbukti dan diterima.

3. Kepemimpinan $\left(X_{1}\right)$ berpengaruh secara langsung, positif, dan signifikan terhadap Motivasi Kerja $\left(\mathrm{Y}_{2}\right)$. Hal ini terlihat dari koefisien jalur yang bertanda positif sebesar 0,144 dengan nilai C.R. sebesar 2,117 dan diperoleh probabilitas signifikansi (p) sebesar 0,034 yang lebih kecil dari taraf signifikansi $(\alpha)$ yang ditentukan sebesar 0,05. Koefisien jalur sebesar 0,144, berarti setiap ada kenaikan Kepemimpinan $\left(X_{1}\right)$ maka akan menaikkan Motivasi Kerja $\left(\mathrm{Y}_{2}\right)$ sebesar 0,144 . Dengan demikian hipotesis 3 terbukti dan diterima.

4. Pengembangan Sumber Daya Manusia $\left(\mathrm{X}_{2}\right)$ berpengaruh secara langsung, positif, dan signifikan terhadap Motivasi Kerja $\left(Y_{2}\right)$. Hal ini terlihat dari koefisien jalur yang bertanda positif sebesar 0,586 dengan nilai C.R. sebesar 5,571 dan diperoleh probabilitas signifikansi $(p)$ sebesar 0,000 yang lebih kecil dari taraf signifikansi $(\alpha)$ yang ditentukan sebesar 0,05 . Koefisien jalur sebesar 0,586, berarti setiap ada kenaikan Pengembangan Sumber Daya Manusia $\left(X_{2}\right)$ maka akan menaikkan Motivasi Kerja $\left(\mathrm{Y}_{2}\right)$ sebesar 0,586. Dengan demikian hipotesis 4 terbukti dan diterima.

5. Kepemimpinan $\left(X_{1}\right)$ berpengaruh secara langsung, positif, dan signifikan terhadap Kinerja Karyawan $\left(\mathrm{Y}_{3}\right)$. Hal ini terlihat dari koefisien jalur yang bertanda positif sebesar 0,215 dengan nilai C.R. sebesar 3,952 dan diperoleh probabilitas signifikansi (p) sebesar 0,000 yang lebih kecil dari taraf signifikansi $(\alpha)$ yang ditentukan sebesar 0,05 . Koefisien jalur sebesar 0,215, berarti setiap ada kenaikan Kepemimpinan $\left(\mathrm{X}_{1}\right)$ maka akan menaikkan Kinerja Karyawan $\left(\mathrm{Y}_{3}\right)$ sebesar 0,215. Dengan demikian hipotesis 5 terbukti dan diterima.

6. Pengembangan Sumber Daya Manusia $\left(\mathrm{X}_{2}\right)$ berpengaruh secara langsung, positif, dan signifikan terhadap Kinerja Karyawan (Y3). Hal ini terlihat dari koefisien jalur yang bertanda positif sebesar 0,497 dengan nilai C.R. sebesar 4,823 dan diperoleh probabilitas signifikansi (p) sebesar 0,000 yang lebih kecil dari taraf signifikansi $(\alpha)$ yang ditentukan sebesar 0,05. Koefisien jalur sebesar 0,497, berarti setiap ada kenaikan Pengembangan Sumber Daya Manusia $\left(\mathrm{X}_{2}\right)$ maka akan menaikkan Kinerja Karyawan $\left(\mathrm{Y}_{3}\right)$ sebesar 0,497. Dengan demikian hipotesis 6 terbukti dan diterima.

7. Kepuasan Kerja $\left(\mathrm{Y}_{1}\right)$ berpengaruh secara langsung, positif, dan signifikan terhadap Motivasi Kerja $\left(\mathrm{Y}_{2}\right)$. Hal ini terlihat dari koefisien jalur yang bertanda positif sebesar 0,225 dengan nilai C.R. sebesar 2,132 dan diperoleh probabilitas signifikansi (p) sebesar 0,033 yang lebih kecil dari taraf signifikansi 
$(\alpha)$ yang ditentukan sebesar 0,05 . Koefisien jalur sebesar 0,225, berarti setiap ada kenaikan Kepuasan Kerja $\left(\mathrm{Y}_{1}\right)$ maka akan menaikkan Motivasi Kerja $\left(\mathrm{Y}_{2}\right)$ sebesar 0,225. Dengan demikian hipotesis 7 terbukti dan diterima.

8. Kepuasan Kerja $\left(\mathrm{Y}_{1}\right)$ berpengaruh secara langsung, positif, dan signifikan terhadap Kinerja Karyawan $\left(\mathrm{Y}_{3}\right)$. Hal ini terlihat dari koefisien jalur yang bertanda positif sebesar 0,277 dengan nilai C.R. sebesar 3,251 dan diperoleh probabilitas signifikansi (p) sebesar 0,001 yang lebih kecil dari taraf signifikansi $(\alpha)$ yang ditentukan sebesar 0,05 . Koefisien jalur sebesar 0,277, berarti setiap ada kenaikan Kepuasan Kerja $\left(\mathrm{Y}_{1}\right)$ maka akan menaikkan Kinerja Karyawan $\left(\mathrm{Y}_{3}\right)$ sebesar 0,277. Dengan demikian hipotesis 8 terbukti dan diterima.

9. Motivasi Kerja $\left(\mathrm{Y}_{1}\right)$ berpengaruh secara tidak signifikan terhadap Kinerja Karya wan $\left(\mathrm{Y}_{3}\right)$. Hal ini terlihat dari koefisien jalur yang bertanda positif sebesar 0,037 dengan nilai C.R. sebesar 0,368 dan diperoleh probabilitas signifikansi $(p)$ sebesar 0,713 yang lebih besar dari taraf signifikansi $(\alpha)$ yang ditentukan sebesar 0,05 . Dengan demikian Motivasi Kerja $\left(\mathrm{Y}_{2}\right)$ tidak berpengaruh secara langsung pada Kinerja Karyawan $\left(\mathrm{Y}_{3}\right)$, hipotesis 9 tidak terbukti dan ditolak.

\section{Pembahasan}

\section{Pengaruh Kepemimpinan $\left(X_{1}\right)$ terhadap} Kepuasan Kerja $\left(\mathrm{Y}_{1}\right)$

Kepuasan kerja karyawan Bank Sulselbar tercipta karena pimpinan Bank Sulselbar memiliki kompetensi dalam melakukan tugas kepemimpinannya, memiliki kemampuan melakukan perencanaan dan pengambilan keputusan yang baik, serta konsekuen dalam menerapkan peraturan kerja yang berlaku yang ditunjukkan dengan pemberian sanksi bagi karyawan yang melanggar kedisiplinan/peraturan yang berlaku. Kondisi berdasarkan kualitas pribadi dan tindakan administratif oleh pimpinan Bank
Sulselbar tersebut menimbulkan kepuasan kerja karyawan, dan karyawan merasa bahwa pengawasan dan penilaian terhadap karyawan telah dilakukan dengan adil, penugasan oleh pimpinan telah dilakukan berdasarkan kompetensi dari tiap-tiap karyawan, serta kebijakan dan peraturan telah diberlakukan secara tegas dan adil oleh pimpinan Bank Sulselbar. Kondisi yang di dalamnya pimpinan menekankan pentingnya kebersamaan dalam menyelesaikan tugas serta selalu menciptakan hubungan yang harmonis dengan para bawahannya juga telah menciptakan kepuasan kerja karyawan terhadap pengelolaan atau manajemen tim kerja yang ada dalam kelompok kerja di Bank Sulselbar.

Temuan ini mendukung hasil penlitian Yukl (2005) dan Pierce and Newstrom (2006) yang menyatakan bahwa perilaku dari seorang pemimpin dapat mempengaruhi kepuasan dari bawahan, dan mendukung teori yang menyatakan bahwa kepemimpinan dapat menghasilkan outcome kepuasan kerja, serta mendukung hasil penelitian Challagalla and Shervani (2006) yang menyatakan bahwa kepemimpinan berpengaruh signifikan terhadap kepuasan kerja karyawan.

\section{Pengaruh Pengembangan Sumber Daya} Manusia $\left(X_{2}\right)$ terhadap Kepuasan Kerja $\left(Y_{1}\right)$

Pengembangan sumber daya manusia di Bank Sulselbar telah dilaksanakan dengan baik. Penempatan karyawan sesuai dengan kemampuan yang dimiliki mencerminkan bahwa penugasan sesuai dengan kompetensi telah dipraktikkan di Bank Sulselbar, kondisi tersebut telah menimbulkan kepuasan kerja karyawan. Penerapan program pelatihan dan pengembangan karir karyawan, yaitu dilaksanakannya pelatihan sesuai dengan jenis pekerjaan karyawan dan dilakukan secara berkelanjutan untuk menambah wawasan karyawan, serta diberikannya kesempatan berkembang kepada setiap karyawan telah menimbulkan kepuasan kerja dan karyawan merasa 
bahwa terdapat kesempatan promosi dan terbuka peluang karir bagi dirinya di lingku ngan kerja Bank Sulselbar.

Temuan ini mendukung hasil penelitian Huselid (1995) dan Whitener (2001) yang menyatakan bahwa komitmen tinggi pada pengembangan sumber daya manusia terbukti secara empiris mempengaruhi hasil (outcome) organisasi melalui pembentukan perilaku dan sikap karyawan. Perilaku dan sikap tersebut ditunjukkan dengan kepuasan, komitmen, dan loyalitas tinggi karyawan terhadap pekerjaan dan organisasi. Mahmudah (2007) juga memberi bukti empi ris bahwa pengembangan sumber daya manusia berpengaruh langsung dan signifikan terhadap kepuasan kerja karyawan.

\section{Pengaruh Kepemimpinan $\left(X_{1}\right)$ terhadap Motivasi Kerja $\left(\mathrm{Y}_{2}\right)$}

Karyawan Bank Sulselbar menilai bahwa kepemimpinan telah dijalankan oleh pimpinan yang berkualitas. Pimpinan Bank Sulselbar dinilai memiliki kompetensi dalam melaksanakan tugas kepemimpinan nya, dalam arti pekerjaan/tugas yang diberikan memiliki tujuan yang jelas serta memberi manfaat bagi karyawan dan Bank Sulselbar, sehingga mampu menciptakan motivasi kerja karyawan. Selain itu, saran/ pendapat dari karyawan secara terbuka diterima oleh pimpinan Bank Sulselbar, kondisi tersebut mencerminkan bahwa terdapat kepercayaan pimpinan atas pelaksana an tugas oleh karyawannya. Kepercayaan pimpinan tersebut mendorong timbulnya motivasi kerja karyawan.

Temuan ini mendukung hasil penelitian Gibson et al. (1992), Webb (2007), dan Pranata (2008) yang menyatakan bahwa kepemimpinan berpengaruh terhadap motivasi kerja. Peran kepemimpinan sangat besar untuk memotivasi anggota organisasi dalam memperbesar energi untuk berperilaku dalam upaya mencapai tujuan kelom pok.

Pengaruh Pengembangan Sumber Daya Manusia $\left(X_{2}\right)$ terhadap Motivasi Kerja $\left(Y_{2}\right)$
Pengembangan sumber daya manusia di Bank Sulselbar telah diterapkan dengan baik, sehingga menciptakan motivasi kerja karyawan. Penempatan karyawan sesuai dengan kemampuannya mencerminkan pekerjaan/tugas yang diberikan mempunyai tujuan yang jelas, kondisi tersebut menimbulkan motivasi kerja karyawan. Pelaksanaan pelatihan secara berkelanjutan sesuai dengan jenis pekerjaan tiap-tiap karyawan serta kesempatan pengembangan karir yang ditunjukkan dengan diterapkannya aturan yang jelas tentang perencanaan dan pengembangan karir juga mendorong motivasi kerja karyawan, karena kondisi tersebut menggambarkan kepercayaan pemimpin kepada karyawan dalam melaksanakan pekerjaan/tugasnya. Bank Sulselbar secara berkala melakukan evaluasi kinerja yang bersifat adil dan transparan serta adanya pemberian jaminan kerja selama karyawan dapat melaksanakan pekerjaan sesuai aturan perusahaan membuat karyawan termotivasi dalam bekerja karena karyawan merasa memperoleh penghargaan atas kinerjanya.

Temuan ini mendukung pendapat Robbins (2002) dan Price (2003) yang menyatakan bahwa pengembangan sumber daya manusia akan berpengaruh terhadap motivasi kerja apabila pengembangan sumber daya manusia dilaksanakan secara sistematis, artinya adanya upaya untuk memaksimalkan potensi karyawan di dalam organi sasi, mencurahkan waktu, biaya, dan pemikiran untuk meningkatkan kompetensi penting yang dimiliki oleh para karyawan. Hal tersebut dapat memotivasi karyawan, meningkatkan keahliannya serta memperlihatkan bahwa karyawan tersebut berharga bagi organisasi. Temuan ini juga mendukung hasil penelitian Youndt et al. (1996) yang menunjukkan bahwa investasi dalam pengembangan sumber daya manusia merepresentasikan suatu strategi komitmen tinggi (high-commitment strategy) yang mempengaruhi kepuasan dan motivasi karyawan. 


\section{Pengaruh Kepemimpinan $\left(X_{1}\right)$ terhadap Kinerja Karyawan $\left(\mathrm{Y}_{3}\right)$}

Kepemimpinan yang dijalankan di Bank Sulselbar terbukti mampu meningkatkan kinerja karyawan. Tindakan administratif telah diterapkan secara tegas dan adil oleh pimpinan Bank Sulselbar sehingga mampu meningkatkan kinerja karyawan. Pimpinan secara konsekuen menerapkan peraturan-peraturan kerja serta memberi sanksi kepada karyawan yang melanggar kedisiplinan/peraturan kerja yang berlaku sehingga mampu meningkatkan kedisiplinan kerja karyawan. Peningkatan kedisiplinan tercermin pada kondisi yang didalamnya karyawan secara kuantitas dapat menyelesaikan jumlah (volume) pekerjaan/ tugas sesuai harapan Bank Sulselbar. Selain itu, kondisi hubungan kerja yang baik dan kondusif juga mampu meningkatkan kinerja karyawan. Pimpinan senantiasa menekan kan pentingnya kebersamaan dalam melaksanakan tugas-tugas perusahaan serta menciptakan hubungan yang harmonis dengan para bawahannya, dan upaya tersebut mam pu menimbulkan dampak interpersonal yang baik dan karyawan mampu bekerja sama dengan semua pihak dalam bekerja.

Temuan ini mendukung hasil penelitian Pranata (2008) dan pendapat Yukl (2005) yang menjelaskan bahwa perilaku atau kepemimpinan dari seorang pemimpin dapat mempengaruhi kinerja bawahan. Namun, temuan ini bertentangan dengan hasil penelitian Mahmudah (2007) yang menyata kan bahwa perilaku pimpinan tidak berpengaruh langsung dan signifikan terhadap kinerja karyawan. Hasil penelitian ini menunjukkan bahwa kepemimpinan di Bank Sulselbar terbukti mampu memberi pengaruh yang bermakna dan positif bagi kinerja karyawan dan dapat membuat karyawan berkinerja baik.

Pengaruh Pengembangan Sumber Daya Manusia $\left(X_{2}\right)$ terhadap Kinerja Karyawan $\left(\mathrm{Y}_{3}\right)$

Pengembangan sumber daya manusia di Bank Sulselbar telah diterapkan dengan baik sehingga terbukti mampu meningkatkan kinerja karyawan. Proses perekrutan karyawan telah dilaksanakan dengan tepat, program pelatihan dan pengembangan telah dilaksanakan sesuai dengan kebutuhan karyawan dan kepentingan perusahaan, kesempatan pengembangan karir bagi karyawan telah diberikan secara adil, penilaian atau evaluasi kinerja telah dilakukan dengan tepat. Kondisi tersebut telah mendorong peningkatan kinerja karyawan yang ditunjukkan dengan adanya penyelesaian jumlah (volume) pekerjaan/tugas sesuai harapan Bank Sulselbar (penyelesaian tugas secara kuantitas), serta terciptanya suasana kerja yang kondusif. Selain itu, penempatan karyawan sesuai dengan kemampuannya mampu mendorong karyawan dapat menye lesaikan pekerjaan/tugasnya. Adanya kesempatan berkembang membuat karyawan senantiasa memiliki motivasi diri (keuletan, kerja keras, integritas, niat, empati, dan ketegasan) dalam melaksanakan pekerjaan. Kondisi-kondisi tersebut mencerminkan bahwa karyawan mampu berkinerja baik.

Temuan ini mendukung hasil pendapat Huselid (1995) dan Whitener (2001) bahwa komitmen tinggi pada pengembangan sumber daya manusia terbukti secara empiris mempengaruhi hasil (outcome) organisasi melalui pembentukan perilaku dan sikap karyawan. Perilaku dan sikap tersebut ditunjukkan dengan kepuasan, komitmen, dan loyalitas tinggi karyawan terhadap pekerjaan dan organisasi.

\section{Pengaruh Kepuasan Kerja $\left(Y_{1}\right)$ terhadap Motivasi Kerja $\left(\mathrm{Y}_{2}\right)$}

Kepuasan kerja yang dirasakan karyawan Bank Sulselbar terbukti mampu memotivasi kerja karyawan. Adanya kepuasan kerja atas kompetensi penugasan oleh pimpinan serta pengawasan dan penilaian yang dilakukan oleh supervisor atau pimpinan telah memotivasi karyawan untuk bekerja dengan baik, karena karyawan merasakan adanya kepercayaan pimpinan terhadap 
karyawan dalam melaksanakan tugas. Kepuasan kerja karyawan dalam hal sistem operating procedure yang telah berjalan dengan baik serta diterapkannya kebijakan dan aturan Bank Sulselbar secara tegas dan adil telah menciptakan orientasi tugas yang jelas, dan karyawan merasakan terdapat tujuan yang jelas atas tugas/pekerjaan yang diberikan kepadanya serta memberi manfaat bagi diri karyawan dan Bank Sulselbar. Kondisi tersebut terbukti dapat menimbulkan motivasi kerja karyawan.

Temuan ini mendukung hasil penelitian Laily (2008). Sikap positif dari setiap karyawan dalam rangka mencapai tujuan yang diharapkan merupakan cerminan dari kepuasan kerjanya. Karyawan yang menikmati kepuasan kerja dalam pekerjaannya akan lebih termotivasi untuk meningkatkan kinerja.

\section{Pengaruh Kepuasan Kerja $\left(\mathrm{Y}_{1}\right)$ terhadap Kinerja Karyawan $\left(\mathrm{Y}_{3}\right)$}

Kepuasan kerja yang diperoleh karyawan Bank Sulselbar terbukti mampu meningkatkan kinerja karyawan. Adanya kepuasan kerja karyawan terhadap pengawasan dan penilaian serta kompetensi penu gasan oleh pimpinan, serta adanya kepuasan kerja karyawan terhadap penerapan sistem operating procedure yang tegas terbukti mampu mendorong karyawan untuk menyelesaikan jumlah (volume) pekerjaan atau tugasnya. Kemampuan karyawan menyelesaikan pekerjaan atau tugasnya mencerminkan kondisi kinerja karyawan yang baik.

Temuan ini mendukung hasil penelitian Laily (2008), Ostroff (2003), dan Laschinger et al. (2001) yang menemukan bahwa kepuasan kerja mempunyai hubungan yang positif dan signifikan terhadap kinerja karyawan. Hasil penelitian ini menunjukkan bahwa kepuasan kerja yang dirasakan oleh karyawan Bank Sulselbar yang terdiri atas supervisi, operating procedures, promosi, dan rekan kerja, mampu memberi pengaruh yang bermakna dan positif bagi kinerja karyawan.

\section{Pengaruh Motivasi Kerja $\left(\mathrm{Y}_{2}\right)$ terhadap Kinerja Karyawan $\left(\mathrm{Y}_{3}\right)$}

Penelitian ini menemukan bahwa motivasi kerja berpengaruh tidak signifikan terhadap kinerja karyawan, artinya bahwa motivasi kerja tidak cukup membuat karyawan berkinerja optimal. Hal ini menunjukkan bahwa karyawan bekerja untuk mencapai target yang ditentukan Bank Sulselbar tanpa disertai oleh kreativitas yang unggul untuk meningkatkan kinerjanya, atau secara tegas dikatakan bahwa karyawan menyelesaikan pekerjaan karena takut kehilangan pekerjaan. Peluang ini memungkinkan terjadinya sejumlah penyimpangan dalam bekerja, baik pemborosan waktu pada saat pekerjaan tidak banyak atau penyimpangan atas pendapatan yang seharusnya diterima perusahaan.

Kinerja merupakan suatu fungsi dari motivasi dan kemampuan. Untuk menyelesaikan tugas atau pekerjaan, seorang karyawan seharusnya memiliki derajat kesediaan dan tingkat kemampuan tertentu. Kesediaan dan keterampilan seseorang tidak efektif tanpa pemahaman yang jelas tentang apa yang dikerjakan dan bagaimana mengerjakannya. Hal ini mengindikasi adanya partisipasi semu karyawan dalam bekerja di suatu perusahaan.

Secara garis besar motivasi dapat bersumber dari faktor internal dan faktor eksternal. Motivasi internal akan mempengaruhi dan mengarahkan perilaku karyawan untuk meningkatkan kinerjanya. Seorang karyawan yang ingin mendapat nilai yang memuaskan dalam penilaian kinerja akan menentukan perilaku karyawan dalam memenuhi syarat penilaian tersebut. Setelah memikirkan dalam-dalam, perilakunya mungkin akan menjadi karyawan yang rajin dalam bekerja, tidak datang terlambat, tidak pernah absen dan mematuhi peraturan, tetapi dalam kenyataan tidak semua karyawan mempunyai keinginan yang kuat untuk mencapai nilai yang memuaskan.

Bank Sulselbar dinilai perlu untuk membenahi budaya organisasinya, artinya pimpinan dan karyawan perlu untuk me- 
ngubah perilaku kerjanya. Perubahan badan hukum dari Perusahaan Daerah (PD) menjadi Perseroan Terbatas (PT) seharusnya didukung dengan peningkatan etos kerja, sehingga karyawan akan lebih kreatif dan inovatif. Perubahan ini diharapkan terjadi di seluruh lingkungan kerja Bank Sulselbar, baik pimpinan/manajemen maupun karyawan Bank Sulselbar.

Temuan ini bertentangan dengan teoriteori sumber daya manusia yang ada dan prediksi teoretis yang menyatakan bahwa motivasi kerja adalah faktor yang sangat penting dalam peningkatan kinerja karyawan. Temuan ini mendukung hasil penelitian Prananta (2008) yang menemukan bahwa motivasi mempunyai hubungan yang positif dan tidak signifikan terhadap kinerja karyawan.

\section{SIMPULAN dan SARAN Simpulan}

Berdasarkan hasil kajian dan hasil uji pengaruh kepemimpinan dan pengembangan sumber daya manusia terhadap kepuasan kerja, motivasi kerja, dan kinerja karyawan Bank Sulselbar, maka ditarik simpulan sebagai berikut:

1. Kepemimpinan berpengaruh langsung, positif, dan signifikan terhadap kepuasan kerja, yang berarti hipotesis satu yang menyatakan kepemimpinan berpengaruh signifikan terhadap kepuasan kerja, terbukti dan diterima.

2. Pengembangan sumber daya manusia berpengaruh langsung, positif, dan signifikan terhadap kepuasan kerja, yang berarti hipotesis dua yang menyatakan pengembangan sumber daya manusia berpengaruh signifikan terhadap kepuasan kerja, terbukti dan diterima.

3. Kepemimpinan berpengaruh langsung, positif, dan signifikan terhadap motivasi kerja, yang berarti hipotesis tiga yang menyatakan kepemimpinan berpengaruh signifikan terhadap motivasi kerja, terbukti dan diterima.
4. Pengembangan sumber daya manusia berpengaruh langsung, positif, dan signifikan terhadap motivasi kerja, yang berarti hipotesis empat yang menyatakan pengembangan sumber daya manusia berpengaruh signifikan terhadap motivasi kerja, terbukti dan diterima.

5. Kepemimpinan berpengaruh langsung, positif, dan signifikan terhadap kinerja karyawan, yang berarti hipotesis lima yang menyatakan kepemimpinan berpengaruh signifikan terhadap kinerja karyawan, terbukti dan diterima.

6. Pengembangan sumber daya manusia berpengaruh langsung, positif, dan signifikan terhadap kinerja karyawan, yang berarti hipotesis enam yang menyatakan pengembangan sumber daya manusia berpengaruh signifikan terhadap kinerja, terbukti dan diterima.

7. Kepuasan kerja berpengaruh langsung, positif, dan signifikan terhadap motivasi kerja, yang berarti hipotesis tujuh yang menyatakan kepuasan kerja berpengaruh signifikan terhadap motivasi kerja, terbukti dan diterima.

8. Kepuasan kerja berpengaruh langsung, positif, dan signifikan terhadap kinerja karyawan, yang berarti hipotesis delapan yang menyatakan kepuasan kerja berpengaruh signifikan terhadap kinerja karyawan, terbukti dan diterima.

9. Motivasi kerja berpengaruh tidak signifikan terhadap kinerja karyawan. Dengan demikian hipotesis sembilan yang menyatakan motivasi kerja berpengaruh signifikan terhadap kinerja karyawan, tidak terbukti dan ditolak.

10. Hasil penelitian ini memberi kontribusi pada ilmu pengetahuan khususnya di bidang ilmu manajemen sumber daya manusia. Pengembangan model teoretis kepuasan motivasi kinerja yang diguna kan dalam penelitian ini dapat diguna kan untuk memecahkan masalah kiner ja karyawan di suatu organisasi/peru sahaan baik mengenai hubungan sebab 
akibat maupun hubungan linier dan persamaan didukung oleh data empirik, yang berarti hasil penelitian mengandung kebenaran keilmuan. Esensi temuan adalah kepemimpinan dan pengembangan sumber daya manusia berpengaruh terhadap kinerja karyawan melalui variabel intervening kepuasan kerja dan motivasi kerja.

11. Hasil penelitian ini dapat memberikan kontribusi bagi kepentingan Bank Sulselbar dan industri perbankan serta industri-industri lainnya dalam upaya meningkatkan kepuasan kerja, motivasi kerja, dan kinerja karyawan melalui kepemimpinan dan pelaksanaan program pengembangan sumber daya manusia dalam rangka peningkatan keunggulan kompetitif dan membangun citra Bank Sulselbar ke arah tata kelola yang baik atau Good Corporate Governance.

12. Model pengembangan teori yang tercermin pada judul penelitian ini dapat menjadi jawaban terhadap rumusan masalah. Kepemimpinan dan pengembangan sumber daya manusia relevan dengan permasalahan untuk meningkat kan kepuasan kerja, motivasi kerja, dan kinerja karyawan. Dengan demikian hubungan pengaruh antar variabel penelitian merupakan model penyederhanaan atas kompleksitas fenomena masalah kepuasan kerja, motivasi kerja, dan kinerja karyawan, sehingga model penelitian ini adalah model problem solving yang baik.

\section{Saran}

1. Kepemimpinan para pemimpin di Bank Sulselbar yang menurut sebagian karyawan dipersepsikan baik, perlu ditingkatkan. Demikian pula dengan Program Pengembangan Sumber Daya Manusia yang sedang dan terus dilakukan oleh Bank Sulselbar dalam rangka peningkatan profesionalisme karyawan, meskipun sebagian karyawan menganggap baik, perlu diting- katkan kualitasnya dan lebih diinternalisasi menjadi inner motivation para karyawan.

2. Motivasi kerja masih dipersepsi paling kecil pengaruhnya dan tidak signifikan terhadap kinerja karyawan. Motivasi kerja karyawan perlu mendapat perhatian manajemen Bank Sulselbar dalam rangka memelihara dan meningkat kan kinerja karyawan dengan cara selalu mengevaluasi kebutuhan-kebutu hannya sebagai manusia organisasional (pekerja) selama masa kerjanya.

3. Bagi para karyawan yang berkinerja cukup baik, hendaknya perusahaan menjaga agar kepuasan kerja dan motivasi kerjanya tidak menurun. Sedangkan bagi karyawan yang kinerja nya kurang baik perlu dipacu dengan faktor motivasional eksternal dan faktor motivasional internal.

4. Bank Sulselbar dinilai perlu untuk membenahi budaya organisasinya artinya pimpinan dan karyawan perlu untuk mengubah perilaku kerjanya. Perubahan badan hukum dari Perusahaan Daerah (PD) menjadi Perseroan Terbatas (PT) seharusnya didukung dengan peningkatan etos kerja, sehingga karyawan akan lebih kreatif dan inovatif. Perubahan ini diharapkan terjadi di seluruh lingkungan kerja Bank Sulselbar, baik pimpinan/manajemen maupun karyawan Bank Sulselbar.

5. Penelitian ini tidak melakukan kajian tentang hubungan yang sama terhadap perusahaan yang sejenis atau bank lain di Sulawesi Selatan. Oleh karena itu, hasil penelitian kemungkinan tidak dapat digeneralisasi terhadap perusahaan yang sejenis atau bank lain di Sulawesi Selatan. Untuk penelitian lebih lanjut disarankan untuk menggunakan variabel-variabel dalam penelitian ini, dalam rangka mengetahui pengaruh antar variabel terhadap perusahaan yang sejenis atau bank lain di Sulawesi Selatan. 
6. Penelitian ini hanya mengkaji beberapa variabel yang berkaitan dengan kepuasan kerja, motivasi kerja, dan kinerja karyawan Bank Sulselbar, yaitu dengan exogenous construct kepemimpinan dan pengembangan sumber daya manusia. Oleh karena itu, diharapkan ada penelitian lanjutan guna melihat secara lebih luas faktor-faktor yang mempengaruhi kepuasan kerja, motivasi kerja, dan kinerja karyawan.

\section{DAFTAR PUSTAKA}

Ayuningtias, L. 2007. Pengaruh Praktik Pengembangan Sumber Daya Manusia terhadap Komitment Organisasi pada Departemen Pemeliharaan I PT. Petrokimia Gresik.http://library@unair.ac.id.

Bernardin, J. H., J. E. A. Russel. 2007. Human Resources Management, An Experimental Approach. International Edition. Mc Graw-Hill. Boston.

Challagalla, N. G. dan A. T. Shervani. 2006. Dimensional and type of Supervisory Control: Effect on Sallesperson Per formance and Satisfaction. Journal of Marketing (60):89-105.

Davis, K. dan J. W. Newstroom. 2001. Perilaku Dalam Organisasi, Jilid 1 dan 2, Penerjemah Agus Dharma. Erlangga. Jakarta.

Gibson, J. L., J. M. Ivancevich, dan J. H. Donnely. 2003. Organisasi (Perilaku, Struktur dan Proses). Edisi kelima. Erlangga. Jakarta.

Hamid, E.S. dan B Rowi. 2003. Membangun Profesional Muhammadiyah. LPTP Muhammadiyah dan UAD Press. Yogyakarta.

Handoko, T. H. 1996. Manajemen Personalia dan Sumber Daya Manusia. Edisi kedua. BPFE. Yogyakarta.

Hassan, A., A. Hashim, dan A. Z. Ismail. 2006. Human Resources Development Practices as Determinant of HRD Climate and Quality Orientation. Journal of European Industrial Training 30(1): 4-18.
Hughes, R. L., R. C. Ginnett, dan G. J. Curphy. 2002. Leadership: Enhancing The Lessons of Experience. McGraw-Hill Companies, Inc. New York.

Huselid, M. A. 1995. The Impact of Human Resource Management Practices on Turnover, Productivity, and Corporate Financial Performance. Academy of Management Journal 38: 635-672.

Kreitner, R. dan A. J. Kinicki. 2004. Organizational Behavior. Sixth Edition. Mc Graw-Hill; International Edition. New York.

Laily, N. 2008. Pengaruh Karakteristik Individu dan Karakteristik Pekerjaan serta Iklim Organisasi terhadap Kepuasan Kerja dan Motivasi kerja serta Kinerja Manajer Menengah Indistri Pupuk Nasional di Indonesia. Disertasi. Universitas Airlangga. Surabaya.

Laschinger, H. K., J. Finegan, dan J. Shamian. 2001. The impact of workplace empowerment, organizational trust on staff nurses's work satisfaction and organizational commitment. Health Care Manage Rev 26(3): 7-23.

Lee, C. H. dan N. T. Bruvold. 2003. Creating Value for Employee: Investment in Employee Development. Journal of Human Resource Management 14(6): 9811000.

Mahmudah, 2007. Pengembangan Sumber Daya Manusia dan Perilaku Pemimpin Pengaruhnya terhadap Kinerja dan Kepuasan Kerja Karyawan. Hibah Penelitian Dosen Muda Tahun 2007 yang biayai oleh Dirjen Dikti Depdiknas. Makalah Semnas "Managemen: Up2Date" tahun 2008. Departemen Manajemen Fakultas Ekonomi Universitas Airlangga. Surabaya.

Mangkunegara, A. P. 2004. Evaluasi Kinerja SDM. PT Refika Aditama. Bandung.

Ostroff, C. 1992. The Relationship Between Satisfaction, Attitudes and Performance An Organization Level Analysis. Journal of Apllied Psychology 77(6): 933973. 
Pierce, J. L. dan J. W. Newstrom. 2006. Leaders and The Leadership Process: Readings, Self Assessments \& Applications. McGraw-Hill Companies, Inc. New York.

Prananta, M. I. 2008. Pengaruh Kepemimpinan dan Budaya Organisasi serta Motivasi terhadap Perilaku Kerja dan Kinerja Karyawan Hotel Berbintang di Kalimantan Timur. Disertasi. Universitas Airlangga. Surabaya.

Price, A. 2003. Human Resource Management in a Business Context. Second Edition. Thomson Learning. London.

Robbins, S. P. 2002. Perilaku Organisasi: Konsep, Kontroversi, Aplikasi. Alih Bahasa Hadyana Pujaatmaka dan Benyamin Molan. Edisi Kedelapan. Jilid 2. Prenhallindo. Jakarta.

Ruvendi, R. 2005. Imbalan Dan Gaya Kepemimpinan Pengaruhnya Terhadap Kepuasaan Kerja Karyawan Di Balai Besar Industri Hasil Pertanian Bogor. Jurnal Ilmiah Binaniaga 1(1):17-26.

Siregar, S. 2009. Pengaruh Pengembangan Sumber Daya Manusia Terhadap Kinerja Pegawai (Studi Kasus Pada Dinas Perhubungan Kota Medan). Skripsi. Universitas Sumatera Utara. Medan.

Sutadji, 2008. Pengaruh Kebijakan Sistem Kompensasi dan Kondisi Kerja serta Kapasitas Individu terhadap Motivasi
Kerja dan Kinerja Karyawan PT. Telekomunikasi, Tbk. Difre VI Kalimantan. Disertasi. Universitas Airlangga. Surabaya.

Webb, K. 2007. Motivating Peak Performance: Leadership Behaviors That Stimulate Employee Motivation And Performance. Christian Higher Education, 6: 53-71.

Winandi, J. 2002. Motivasi dan Pemotivasian dalam Manajemen. Rajawali Press. Jakarta.

Whitener, E. M. 2001. High Commitment Human Resource Practices Affect Employee Commitment? A Cross-Level Analysis Using Hierarchical Linear Modelling. Journal of Management 27: 515-535.

Youndt, M. A., S. A. Snell, J. W. Dean, J.W., dan D. P. Lepak. 1996. Human Resource Management, Manufacturing Strategy, and Firm Performance. Academy of Management Journal 39: 836-866.

Yukl, G. 2005. Kepemimpinan dalam Organisasi. Edisi Kelima. Alih Bahasa Budi Supriyanto. PT Indeks Kelompok Gramedia. Jakarta. 